DOI: $10.14451 / 2.158 .35$

\title{
ПОРЯДОК СОПРОВОЖДЕНИЯ СУДЕБНЫХ ДЕЛ ПРИ ПРИМЕНЕНИИ НОРМ АНТИМОНОПОЛЬНОГО ЗАКОНОДАТЕЛЬСТВА
}

\author{
(C) 2021 Сугак Иван Васильевич \\ E-mail: sugak.v@mail.ru
}

В настоящее время судами рассматривается существенное количество дел, связанных с нарушениями антимонопольного законодательства России. Антимонопольные дела относятся к одним из самых сложных категорий дел, поскольку предполагают высокий уровень компетенций в области доказывания.

Адвокаты как профессиональные защитники прав и интересов лиц обладают специальными юридическими знаниями и опытом осуществления полномочий представителя в суде. Законодательство предоставляет адвокату широкие полномочия, которые позволяют ему содействовать осуществлению права на квалифицированную юридическую помощь, в том числе по антимонопольным спорам.

В связи с изложенным, в настоящее время особый научный и практический интерес состоит в исследовании вопросов сопровождения адвокатом судебных дел при применении норм антимонопольного законодательства.

В настоящее время ощущается нехватка работ, посвященных комплексному исследованию вопросов сопровождения адвокатом судебных дел при применении норм антимонопольного законодательства. В связи с этим существенно возрастает потребность исследования данной темы.

Объект исследования - правоотношения, связанные с осуществлением деятельности адвоката при сопровождении судебных дел по антимонопольным спорам.

Предмет исследования - деятельность адвоката при сопровождении судебных дел по антимонопольным спорам.

Теоретико-методологическая и практическая значимость работы состоит в том, что разработанные в ней выводы, положения и рекомендации могут быть использованы: при проведении дальнейших разработок по теме исследования, при совершенствовании правовых норм, регулирующих различные вопросы деятельности адвоката в судебном процессе, в практической деятельности адвокатов.

Ключевые слова: адвокат, суд, антимонопольные органы, антимонопольное законодательство, антимонопольные споры, исковое заявление, доказательства, защита прав и интересов.

Антимонопольное законодательство, реализуя задачи поддержки конкуренции, свободы экономической деятельности, а также недопущения экономической деятельности, направленной на монополизацию и недобросовестную конкуренцию, вместе с тем стоит на страже прав и законных интересов частноправовых субъектов, обеспечивая для них указанные свободы и защищая от монополистической деятельности и недобросовестной конкуренции*.

Суды в части рассмотрения ими споров на основании предписаний конкурентного законодательства играют крайне важную роль. Именно суды являются той «последней» инстанцией, которая творит право, воплощает идеальное со- держание нормативно-правовых конструкций в реальную жизнь. Решения судов во многих случаях встают на пути монополизации рынка, недобросовестной конкуренции, помогают антимонопольным органам защищать права рядовых граждан и организаций в сфере антимонопольных отношений.

Таким образом, суды обеспечивают эффективность функционирования системы защиты экономической конкуренции, способствуя углублению общественного понимания необходимости установления и поддержания четких, прозрачных и, самое главное, действенных правил экономической конкуренции в сфере хозяйствования. Это достигается благодаря бес-

* Егорова М.А.Гражданско-правовые последствия нарушений антимонопольного законодательства: монография. М.: Юстицинформ, 2020 // СПС «Консультант Плюс». 
пристрастному и высокопрофессиональному рассмотрению судами конкурентных споров.

Адвокат является одним из основных субъектов защиты прав и интересов лиц в сфере антимонопольных отношений. Адвокат поможет разобраться и применить необходимые правовые нормы, чтобы отстоять нарушенное либо защитить оспариваемое право, свободы либо законные интересы. Поэтому обращение к услугам адвоката увеличивает вероятность благополучного исхода дела.

Сопровождение адвокатом судебного дела при применении норм антимонопольного законодательства включает консультирование, подготовку документов и доказательств, участие в судебных заседаниях, дачу пояснений по сути спора, при необходимости - обжалование судебного акта.

Сопровождение судебных споров с антимонопольными органами предусматривает:

- оспаривание в суде решений, предписаний и постановлений антимонопольных органов;

- представление в суде интересов, связанных с применением норм антимонопольного законодательства.

Услуги адвоката по антимонопольным спорам подразумевают, в первую очередь, юридическую консультацию, цель которой - правовая оценка оснований конфликта. В процессе консультации адвокат разъясняет права и обязанности сторон, проводит оценку оснований к спору, обозначает объем нарушенных прав либо законных интересов, анализирует причины к образовавшемуся спору и перспективы его разрешения в досудебном либо судебном порядке.

Консультирование в данной сфере осуществляется:

- по вопросам обжалования решений, предписаний и постановлений антимонопольных органов;

- по вопросам обжалования действий заказчика, закупочной комиссии;

- по вопросам соответствия документов и действий (бездействия) положениям антимонопольного законодательства;

- при проверках, проводимых антимонопольными органами, и пр.

По завершении консультирования адвокат приступает к составлению искового заявления (заявления), содержание которого формирует изначальное оценку требований судом. Исковое заявление (заявление) должно содержать нормативно и документально обоснованные требования в защиту прав и законных интересов доверителя.

До возбуждения дела адвокат совершает необходимые подготовительные мероприятия, в рамках которых он определяет круг доказательств, обосновывающих требования истца и опровергающих доводы другой стороны. При этом адвокат реализует права, которыми он наделен по Закону об адвокатской деятельности. Адвокат анализирует сложившуюся ситуацию с учетом данных, полученные от доверителя, а также норм закона, актуальной судебной практики.

В ходе подготовки к ведению дела адвокатпредставитель составляет досье, т.е. собрание документов, их копий, выписок и других материалов, необходимых для ведения дела*.

Формирование позиции по делу, обеспечение адвоката необходимыми для этого документами и сведениями, а также надлежащая защита интересов доверителя зависят от оперативных действий адвоката по сбору доказательств. Письменные доказательства, документы имеют важное значение для антимонопольных споров. Для получения доказательств закон наделяет адвоката правом запрашивать документы из различных госорганов и организаций; опрашивать лиц; собирать и представлять предметы и документы; привлекать специалистов. Следовательно, адвокат является самостоятельным носителем права на собирание доказательств.

Анализ судебной практики показывает, что с участием адвоката в судебном процессе возрастает эффективность доказательственной деятельности сторон. Качественная работа по сбору доказательств способствует восполнению судом пробелов в доказательствах, своевременному рассмотрению и разрешению спора. Собирание необходимых сведений формирует надлежащую информационную базу адвокатской деятельности.

Поскольку в Законе об адвокатской деятельности говорится о возможности «собирать ... и иные документы», можно сделать вывод, что перечень сведений, которые вправе собирать адвокат, не является исчерпывающим. Не явля-

\footnotetext{
* Адвокатура в России: учебник для вузов / под общ. ред. В.И. Сергеева. 5-е изд., перераб. и доп. М.: Юстицинформ, 2019 // СПС «Консультант Плюс».
} 
ются исчерпывающими и те структуры, которым адвокат вправе направлять запросы и которые обязаны выдавать адвокату запрошенные документы или заверенные надлежащим образом копии.

Разбирательство в суде - стадия публичная, проводимая с участием всех субъектов процесса. Как известно, неоднозначность смысла современных норм, которые заложены в самой норме права, а также право внутреннего убеждения позволяют судам озвучивать решения, оперируя свободным принципом трактования правовых норм. Поэтому участие адвоката действительно важно. Ключевой задачей адвоката является участие в исследовании и оценке доказательств, с использованием имеющихся у него знаний и навыков.

Особого внимания заслуживает речь адвоката в прениях, которая должна быть пронизана уважением к закону, содержать логически выстроенную позицию, а также этический подтекст, показывающий нравственно-справедливый характер этой позиции*. В ходе прений адвокат проводит анализ и оценку доказательств для формирования у суда убеждения в верности и обоснованности своей позиции.

По нашему мнению, участие адвоката как профессионального представителя в судебных прениях связывается с возложением на указанного субъекта особой ответственности за надлежащую деятельность по предоставлению профессиональной юридической помощи. Адвокат, выступая в судебных прениях, фактически подводит итог проделанной работе на предыдущих этапах рассмотрения дела судом. Поэтому внимательность и профессионализм, которым должны обладать адвокаты как профессиональные представители, позволит должным образом аргументировать свою позицию относительно того, которое, по их мнению, должен принять решение суд по делу, что, в свою очередь, положительно повлияет на качество предоставленной профессиональной юридической помощи.

Приведем пример участия адвоката в деле по данной категории споров.

Так, ООО «КАУ» обратилось в суд с заявлением о признании незаконными решения комиссии УФАС по Курской области от 22.11.2019 и предписания от 22.11.2019 об отмене протокола торгов.
На участие в аукционе поступила одна заявка - гражданина Синицына А.В., зарегистрированная оператором ЭТП 19.10.2019 в 17 час. 49 мин. под номером 90589. Синицын А.В. не был допущен организатором торгов к участию в аукционе по причине несоответствия заявки на участие в торгах требованиям, установленных Федеральным законом от 26.10.2002 № 127-ФЗ.

В УФАС поступила жалоба гражданина Синицына А. В. на действия ООО «КАУ» при проведении аукциона, открытого по составу участников, с закрытой формой представления предложений о цене по продаже имущества должника - 3АО «ПТФ «Авторус-94» (аукцион № 0043520 лот № 1). По результатам рассмотрения жалобы, решением Комиссии УФАС организатор торгов - ООО «Компания по антикризисному управлению» признан нарушившим порядок проведения торгов, установленный ч. 12, ч. 15 ст. 110 Федерального закона от 26.10.2002 № 127-Ф3, п. 5.3, 5.1 раздела V Порядка, утвержденного Приказом Минэкономразвития России от 23.07.2015 № 495.

На основании данного решения антимонопольным органом вынесено предписание от 22.11.2019, которым организатору торгов № 0043520 - ООО «КАУ» предписано отменить протоколы данных торгов по лоту № 1 от 23.10.2019 и рассмотреть поступившую на участие в аукционе по лоту № 1 заявку.

Как пояснил адвокат заявителя, в соответствии с опубликованными требованиями к проведению спорных торгов участник торгов физическое лицо к заявке должен был также приложить согласие на обработку персональных данных. Такого согласия ни от Синицына А.В., ни от Ченцова А. М., чьи документы также были приложены к заявке, и фактически внесшего задаток, организатору торгов не поступило.

Таким образом, антимонопольный орган необоснованно установил в оспариваемом решении, что согласие на обработку персональных данных было дано указанными лицами недвусмысленно и однозначно, поскольку за такое «недвусмысленное» согласие антимонопольный орган принял документ word, без подписи, поименованный заявителем не Согласие на обработку персональных данных, а «Заявка на торги».

Кроме этого, как отметил адвокат заявителя, платежного поручения об уплате задатка от Синицына А. В. к заявке также не было приложе-

\footnotetext{
Адвокатура в Российской Федерации: Учебник / Л.А.Стешенко, Т. М.Шамба. 2-е изд., перераб. М.: Норма, 2008. C. 314.
} 
но. Из полномочий доверенности, приложенной Синицыным А.В., не следовало, что ему гражданином Ченцовым А.М. были переданы полномочия на участие в спорных торгах, а также полномочия на подписание от имени Ченцова А. М. согласия на обработку персональных данных гражданина Ченцова А. М.

По условиям торгов, содержались обязательные требование о подписании претендентами договора задатка, проект которого был приложен к объявлению о проведении торгов. Однако к заявке Синицына А.В. такого договора, даже подписанного в одностороннем порядке, также приложено не было.

Назначение платежа суммы задатка, произведенного гражданином Ченцовым А. М., не соответствовало конкурсной документации и требованиям торгов, опубликованным организатором торгов и утвержденным залоговым кредитором в отношении торгов залогового имущества $3 А О$ «ПТФ «Авторус - 94». В частности, лицом не было указано, во исполнение какого договора задатка вносится указанный задаток.

Таким образом, антимонопольным органом не приведено достаточных доказательств того, что документы, приложенные к заявке Синицына А.В., содержали документы, необходимые для допуска к торгам данного претендента, а также не доказано наличие в действиях организатора торгов (ООО «КАУ») нарушений Закона о банкротстве при проведении торгов по реализации имущества должника.

При таких обстоятельствах оспариваемое заявителем решение УФАС от 22.11.2019 и предписание УФАС от 22.11.2019 об отмене протоколов торгов признаны судом недействительными как несоответствующие нормам Закона о банкротстве, и нарушающие права и законные интересы заявителя*.

Таким образом, благодаря аргументированной позиции адвоката, суд признал недействительным решение и предписание антимонопольного органа об отмене торгов недействительными, а решение заказчика о недопуске лица к участию в аукционе - обоснованным.

На основании изложенного, представительство адвоката по делу об антимонопольном споре - это деятельность представителя, соответствующего предъявляемым к нему требованиям, установленным законодательством РФ, в целях оказания квалифицированной юридической помощи представляемому и осуществляемая от его имени и в его интересах, реализуемая при рассмотрении и разрешении антимонопольного спора судом.

\section{Библиографический список}

1. Адвокатура в Российской Федерации: Учебник / Л.А. Стешенко, Т. М.Шамба. 2-е изд., перераб. М.: Норма, 2008.

2. Адвокатура в России: учебник для вузов / под общ. ред. В.И. Сергеева. 5-е изд., перераб. и доп. М.: Юстицинформ, 2019 // СПС «Консультант Плюс».

3. Егорова М.А. Гражданско-правовые последствия нарушений антимонопольного законодательства: монография. М.: Юстицинформ, 2020 // СПС «Консультант Плюс».

*https://sudact.ru/. 